\title{
COMPARATIVE STUDY OF EGYPTIAN BLUE FRAGMENTS FROM EGYPT AND TUNISIA
}

\author{
Moussa, A. \\ Lecturer. Conservation dept., Faculty of Archaeology, Cairo Univ., Cairo, Egypt \\ E-mail: dr_abubakr@msn.com
}

\begin{abstract}
Ancient Egyptians have the intellectual property rights of the manufacturing processes of the blue pigment known as Egyptian blue; this blue pigment was identified later on in many ancient artifacts allover the world. This paper aims to determine either the Egyptian blue was manufactured in Egypt and then exported, or the technology and the raw materials were exported only. For this purpose five bulk blue pigment samples (four from Jerba-Tunisia and one from Saqqara-Egypt) were studied by means of XRD and FTIR in order to determine their mineralogical and chemical composition. The study proved that Egyptian blue is the dominant component in all the samples with different ratios in a variety of mixed materials.
\end{abstract}

Keywords: Egyptian blue, Azurite, XRD analysis, FTIR spectroscopy, Jerba, Saqqara

\section{Introduction}

The studied samples date back to the Roman era; they come from the excavated remains of the ancient harbour of Jerba in Tunisia, and the excavations of the Faculty of Archaeology at Saqqara - Egypt. Djerba (Jerba-Girba) was the island of the Lotus-Eaters where Odysseus stranded on his voyage through the Mediterranean. The island, called Meninx until the third century AD [1], was densely inhabited in the Roman and Byzantine periods, and probably imported much of the grain consumed by its inhabitants. A collapse can be seen after 650 A.D., when the Justinianic plague may have struck the port of Meninx, an archaeological field survey of Jerba, carried out under the auspices of the University of
Pennsylvania, the American Academy in Rome and the National Tunisian Institute of Heritage between 1995 and 2000, revealed over 400 archaeological sites, including many Punic and Roman villas. Saqqara is a vast, ancient burial ground in Egypt, serving as the necropolis for the ancient Egyptian capital, Memphis. Saqqara features numerous pyramids as well as a number of mastabas (Arabic word meaning 'bench'). At Saqqara, the oldest complete stone building complex known in history was built: during the third dynasty: Djoser's step pyramid. Other 16 Egyptian kings built pyramids at Saqqara, which are now in various states of preservation or dilapidation. High officials added private funeral monuments to this necropolis during the entire pharaonic period. It remained an important complex for non-royal burials and cult ceremonies 
for more than 3000 years, well into Ptolemaic and Roman times [2]. The number of reports dealing with Egyptian blue has been remarkably increasing in the last few years, also on non-specialized journals. Egyptian Blue (EB) appeared in Egypt during the third millennium before the Common Era; its first use was in the south tomb of king Djoser from the third pharaonic dynasty [3], and was used at least for 3000 years as a precious pigment, spreading in the whole Roman Empire. After the decline of the Roman Empire itself, the use of this synthetic pigment disappeared. This seems to be related to the loss of the chemical and technological knowledge required for the synthesis of this pigment. At the beginning of the 20th century, Fouque [4] and Laurie et al. [5] attempted both the synthesis of this compound and the study of the effects of cooking

\section{Materials and Methods}

The blue pigment fragments were sampled for laboratory analyses to determine their chemical composition. Xray diffraction (XRD) analysis was performed using powdered samples of the pigment materials using a Philips (PW1840) diffractometer with Ni-filtered $\mathrm{Cu}-\mathrm{K} \alpha$ radiation. The samples were scanned over the $5-60^{\circ} 2 \theta$ intervals at a scanning speed of $1.2^{\circ} \mathrm{min}^{-1}$. A quantitative estimate of the abundance of the mineral phases was derived from the XRD data using the intensity of certain reflections and external standard mixtures of minerals compared to the JCPDS

\section{Results}

\subsection{XRD analyses:}

The XRD analyses of the four samples that came from the excavated remains of the ancient harbor of Jerba in Tunisia; proved that the first sample, fig. (1-a) is composed of $44 \%$ Egyptian blue, $44 \%$ quartz, $9 \%$ calcite and $3 \%$ magnetite. The second sample, fig. (1-b), which belongs to the same excavations, is composed of $56 \%$ quartz, $24 \%$ Egyptian blue, $11 \%$ gypsum and $9 \%$ calcite. The temperature and of the concentration of the fluxes. The use of X-rays allowed the characterization of $\mathrm{EB}$ as a calciumcopper tetra-silicate $\left(\mathrm{CaCuSi}_{4} \mathrm{O}_{10}\right)$. Moreover, it allowed to ascertain that EB and the mineral cuprorivaite, discovered by Minguzzi in the Vesuvio lava in 1938 [6], are actually the same material. In more recent years, many researchers got involved into the production and characterization of EB with different procedures and techniques of analysis, but there is not a final conclusion yet about the role of the different materials and melting temperature [7]. This paper aims to determine either the Egyptian blue was manufactured in Egypt and then exported, or only the technology and the raw materials were exported.

standards of 1967 [8]. Due to the sensitivity of the FTIR instrument, the most convenient and satisfactory method involves simple evaporation of the sample solution (using a solvent such as: chloroform, ether, dichloromethane) onto a $\mathrm{KBr}$ salt plate and acquisition of the spectrum from the thin film remaining. The estimated time to obtain spectrum from a routine sample varies from 1 to 10 minutes [9]. The samples were analyzed as $\mathrm{KBr}$ pellet by a JASCO FTVIR spectrometer (model 460, 400-4000 $\mathrm{cm}^{-1}, \quad 4 \mathrm{~cm}^{-1}$ resolution), in the transmission mode.

third sample from Jerba, it is composed of $67 \%$ quartz, $18 \%$ Egyptian blue and $15 \%$ calcite. The last sample from Jerba, fig. (1-c), it is made of $62 \%$ quartz, $22 \%$ calcite, $11 \%$ Egyptian blue and $5 \%$ magnetite. The comparative sample from Saqqara-Egypt (fifth sample) is a pure sample, made of $100 \%$ Egyptian blue, fig. (1-d). 

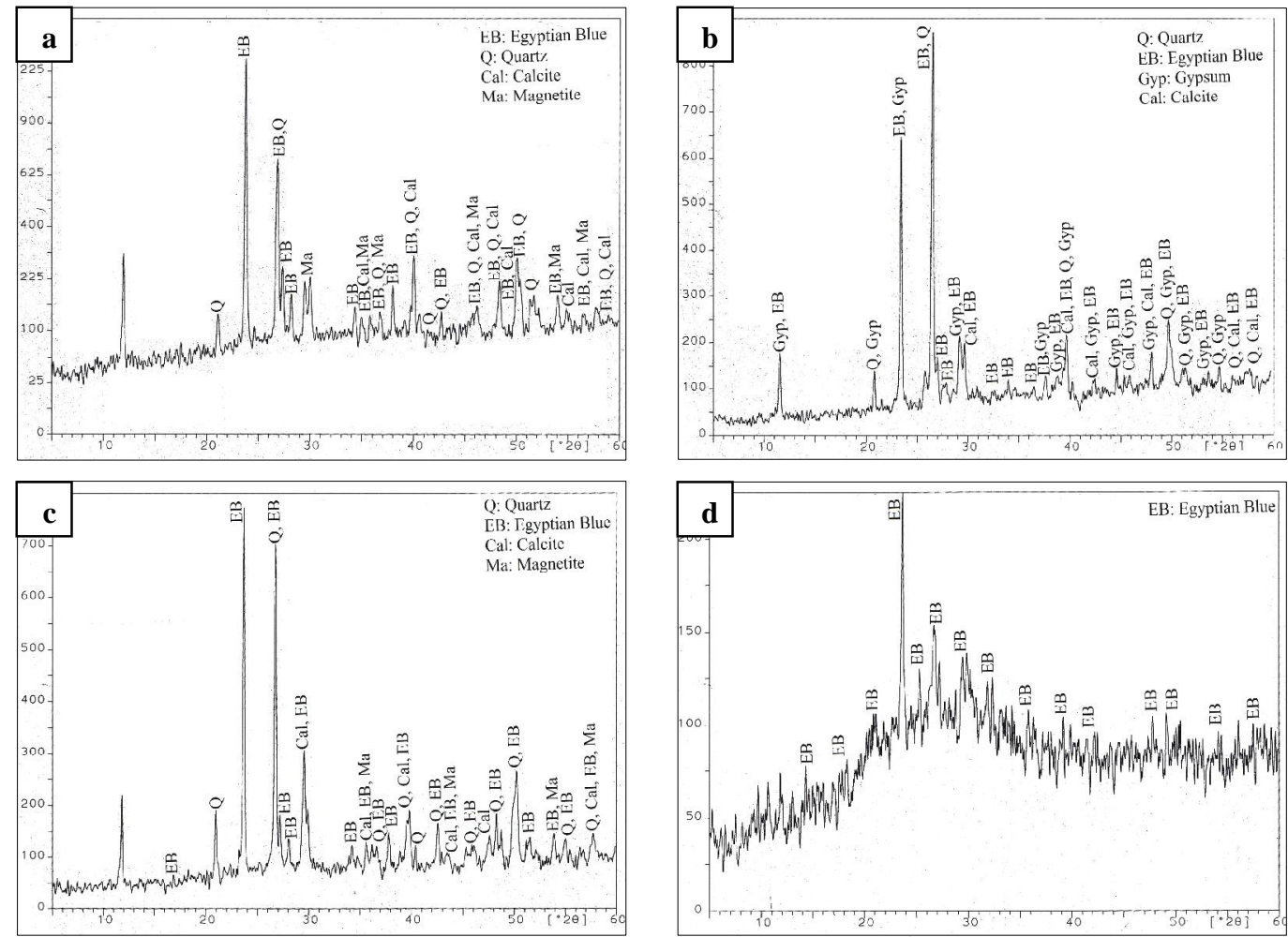

Figure (1) XRD patterns showing $\underline{\mathbf{a}} 1^{\text {st }}$ sample from Jerba, Tunisia, $\underline{\mathbf{b}} 2^{\text {nd }}$ sample from Jerba, Tunisia, $\underline{\mathbf{c}}$ $3^{\text {rd }}$ sample from Jerba, Tunisia, $\underline{\mathbf{d}}$ sample from Saqqara, Egypt (a comparative sample)

\subsection{FTIR analyses:}

The FTIR spectra recorded on $\mathrm{KBr}$ pellets of the pigment samples derived from Jerba proved the following: the FTIR spectrum obtained from the first sample, fig. (2-a) shows the characteristic bands of silicates at $1165 \mathrm{~cm}^{-1}(\mathrm{Si}-\mathrm{O}-$ Si stretching bands), $1057 \mathrm{~cm}^{-1}(\mathrm{Si}-\mathrm{O}-$ $\mathrm{Si}$ bending bands) and at $1006 \mathrm{~cm}^{-1}(\mathrm{Si}-$ $\mathrm{O}-\mathrm{Si}$ rocking bands). The FTIR spectrum obtained from the second sample, fig. (2-b) shows the characteristic bands of silicates at $1077 \mathrm{~cm}^{-1}(\mathrm{Si}-\mathrm{O}-$ Si stretching bands), $763 \mathrm{~cm}^{-1}(\mathrm{Si}-\mathrm{O}-$ Si bending bands) and at $475 \mathrm{~cm}^{-1}(\mathrm{Si}-$ $\mathrm{O}-\mathrm{Si}$ rocking bands), in this sample it was noticed that the absorption peak was shifted from $1057 \mathrm{~cm}^{-1}$ to $1077 \mathrm{~cm}^{-1}$; moreover; the absorption peak at 1165 $\mathrm{cm}^{-1}$ has disappeared. The third sample from Jerba, fig. (2-c) has shown the characteristic bands of calcite at 1876 $\mathrm{cm}^{-1}$ ( $\mathrm{C}=\mathrm{O}$ stretching), $1425 \mathrm{~cm}^{-1}$ (C = $\mathrm{O}$ stretching) and at $883 \mathrm{~cm}^{-1}(\mathrm{C}=\mathrm{O}$ bending); the same sample has shown the characteristic bands of silicates at 1077 $\mathrm{cm}^{-1}$ (Si - O - Si stretching bands), 1008 $\mathrm{cm}^{-1}$ ( $\mathrm{Si}-\mathrm{O}-\mathrm{Si}$ bending bands) and at $474 \mathrm{~cm}^{-1}$ ( $\mathrm{Si}-\mathrm{O}-\mathrm{Si}$ rocking bands). In this sample it was noticed that the absorption peak was shifted from 1057 $\mathrm{cm}^{-1}$ to $1077 \mathrm{~cm}^{-1}$; moreover; the absorption peak at $1165 \mathrm{~cm}^{-1}$ has disappeared. The last sample from Jerba (sample four) has shown the characteristic bands of calcite at 1876 $\mathrm{cm}^{-1}$ ( $\mathrm{C}=\mathrm{O}$ stretching), $1426 \mathrm{~cm}^{-1}(\mathrm{C}=$ $\mathrm{O}$ stretching) and at $880 \mathrm{~cm}^{-1}(\mathrm{C}=\mathrm{O}$ bending). The same sample has shown the characteristic bands of silicates at $1079 \mathrm{~cm}^{-1}$ ( $\mathrm{Si}-\mathrm{O}-\mathrm{Si}$ stretching bands), $1011 \mathrm{~cm}^{-1}$ ( $\mathrm{Si}-\mathrm{O}-\mathrm{Si}$ bending bands) and at $473 \mathrm{~cm}^{-1}(\mathrm{Si}-\mathrm{O}-\mathrm{Si}$ rocking bands), in this sample it was noticed that the absorption peak was shifted from $1057 \mathrm{~cm}^{-1}$ to $1079 \mathrm{~cm}^{-1}$; moreover; the absorption peak at $1165 \mathrm{~cm}^{-1}$ has disappeared. The comparative sample from Saqqara-Egypt, fig. (2-d) shows the characteristic bands of silicates at 1164 $\mathrm{cm}^{-1}$ ( $\mathrm{Si}-\mathrm{O}-\mathrm{Si}$ stretching bands), 1059 $\mathrm{cm}^{-1}$ ( $\mathrm{Si}-\mathrm{O}-\mathrm{Si}$ bending bands) and at $1005 \mathrm{~cm}^{-1}$ ( $\mathrm{Si}-\mathrm{O}-\mathrm{Si}$ rocking bands). 

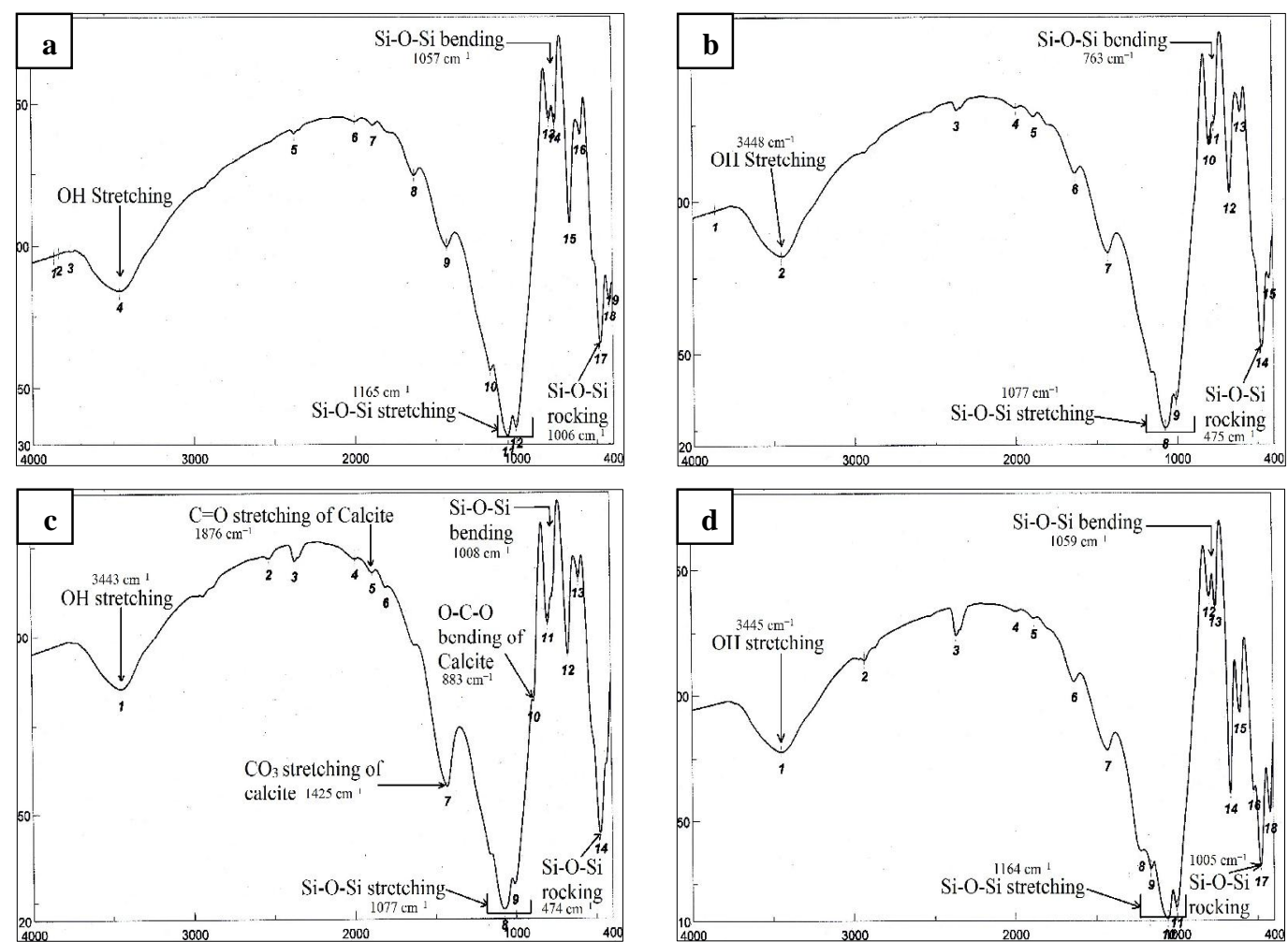

Figure (2) FTIR spectrum showing $\underline{\mathbf{a}} 1^{\text {st }}$ sample from Jerba, Tunisia, $\underline{\mathbf{b}} 2^{\text {nd }}$ sample from Jerba, Tunisia, $\underline{\mathbf{c}} 3^{\text {rd }}$ sample from Jerba, Tunisia, $\underline{\mathbf{d}}$ sample from Saqqara, Egypt (a comparative sample)

\section{Discussion:}

Previous authors have identified the Egyptian blue in many archaeological sites all over the world, for example; the pigment has been used in Cripta del Museo and Alcazaba, also in Casa Del Mitreo in Emerita Augusta, Mérida (Spain), [10][11], it has been also detected in Vicenza and Pordenone (Italy), [12][13], in Reims and Narbonne (France), [14], also in Monte Athos and Crete (Greece), [15][16]. Egyptian blue is a synthetic pigment composed of various phases containing silica, copper and

calcium, made by heating together silica, copper alloy filings or a copper such as malachite, calcium oxide, and an alkali such as potash or natron (sodium sesquicarbonate $\mathrm{Na}_{2} \mathrm{CO}_{3} \cdot \mathrm{NaHCO}_{3} \cdot 2 \mathrm{H}_{2} \mathrm{O}$, found naturally occurring in Egypt in Wadi El Natrun). The melting point was lowered to below $742{ }^{\circ} \mathrm{C}$ by the addition of the alkali. Chemically the combination of malachite, silica and calcite produces cuprorivaite, carbon-dioxide and water vapor according to the following reaction:

$$
\mathrm{Cu}_{2} \mathrm{CO}_{3}(\mathrm{OH})_{2}+8 \mathrm{SiO}_{2}+2 \mathrm{CaCO}_{3} \rightarrow 2 \mathrm{CaCuSi}_{4} \mathrm{O}_{10}+3 \mathrm{CO}_{2}+\mathrm{H}_{2}
$$

This crystalline product consists of rectangular blue crystal, often in many layers. The major component is cuprorivaite $\mathrm{CaCuSi}_{4} \mathrm{O}_{10}$ with unreacted quartz, accompanied by copper-bearing wollastonite $(\mathrm{CaCu})_{3}\left(\mathrm{Si}_{3} \mathrm{O}_{9}\right)$, [17]. PagèsCamagna and Colinart (2003) noted that to produce an ideal Egyptian blue the mixture must be heated at between $870{ }^{\circ} \mathrm{C}$ and $1080{ }^{\circ} \mathrm{C}$ [18], while there is a general agreement on the working temperature that must be kept between $850{ }^{\circ} \mathrm{C}$ and $950{ }^{\circ} \mathrm{C}$ [19]. Bianchetti et al., 2000 included the production and characterization of the Egyptian blue and the Egyptian green frit concluding that when muffle temperature _in the manufacturing process of the Egyptian blue_ is raised up to $1050{ }^{\circ} \mathrm{C}$, the complete transformation of cuprorivaite 
into green glass (a green frit) was observed. Heating procedure and mixture composition affect the appearance of wollastonite, a mineral that was always detected in green frit; at $850{ }^{\circ} \mathrm{C}$, wollastonite was detected in mixtures containing a lower copper: calcium ratio; at higher temperatures, the direct warming up to $1050{ }^{\circ} \mathrm{C}$ did not allow the formation of wollastonite [20]. Kendrick et al., (2005) studied structurally the different families of the Egyptian blue $\left(\mathrm{CaCuSi}_{4} \mathrm{O}_{10^{-}} \mathrm{SrCuSi}_{4} \mathrm{O}_{10^{-}} \quad \mathrm{BaCuSi}_{4} \mathrm{O}_{10}\right)$ noting that the change of the alkali leads to a related changes in the chemical bonds inside the solid solution of the pigment material [21]. Mazzocchin et al., (2004) studied the feasibility of the reaction synthesis of the Egyptian blue in molten alkaline carbonates; three "dry ways" were performed: the stoichiometric one, with $\mathrm{Na}_{2} \mathrm{CO}_{3}$ as a flux, the Schippa and Torraca recipe, and a "Bolognese" method, which uses $\mathrm{NaHCO}_{3}$ as a flux. Good results in color and yields were obtained with the Schippa and Torraca recipe, with the stoichiometric molar ratio and with the "Bolognese method" at $860{ }^{\circ} \mathrm{C}$, good yields in Egyptian blue were obtained with stoichiometric calcium, copper and silica ratios, using $\mathrm{Na}_{2} \mathrm{CO}_{3}$ as a flux. The reiterated grinding of the products had a positive effect [19]. According to the XRD analyses, it has been observed that Egyptian blue is not the dominant component of the samples from Jerba, quartz has the highest ratio in all these samples, Uda et al., (1993) analyzed successfully, by external PIXE with the aid of the X-ray diffraction pigments painted on Egyptian excavations from the $18^{\text {th }}$ Dynasty noting that the Egyptian blue was found on the X-ray diffraction patterns together with small amounts of quartz and gismondine [22]. Calcite and gypsum were also found abreast with quartz and Egyptian blue in some samples from Jerba, this is an indicator to their use as fluxes in the manufacturing process to reduce the melting temperature, their existence as separate compounds in the final production can be noted as a manufacturing defect, no complete melting of the compounds happened. The optical investigation supports this hypothesis as the Tunisian samples are very dark in color and very rough in texture and hardness, the later is supported by the presence of magnetite in some samples. Concerning FTIR, the scarce amount of data available on the subject of infrared characterization of Egyptian blue is a problem for conservators; it must be noted that the process of the synthesis must involve careful monitoring of the reaction condition, otherwise the risk of occurrence of accidental byproducts such as quartz, wollastonite, amorphous glass phases, tenorite and couprite is quite high [23]. According to the FTIR analyses, the dominant bands are due to the presence of silicates, the bands at 473,474 and 475 $\mathrm{cm}^{-1}$ indicate the presence of amorphous silicate phase coming from quartz; the characteristic bands of calcite are present. Moreover, the shift happened to the absorption peak from $1057 \mathrm{~cm}^{-1}$ to 1079 $\mathrm{cm}^{-1}$, while the disappearance of the absorption peak at $1165 \mathrm{~cm}^{-1}$ is probably due to the presence of gypsum and magnetite in addition to the difference in melting temperature between the samples. The different spectral features observed should actually be ascribed to different compounds, but most of them are belonging to the silicate group.

\section{Conclusion}

Based on the results of both XRD and FTIR analyses, it has been concluded that the bulk Egyptian blue samples brought from Jerba - Tunisia are not pure Egyptian blue; they contain different ratios of quartz, calcite, gypsum and magnetite, color and hardness in addition to the presence of amorphous phases in the FTIR spectra are all referring to manufacturing defects in these samples. The comparative bulk sample from Saqqara - Egypt is completely pure Egyptian blue. The aforementioned data refer to: 
- Egyptian blue pigment found outside Egypt was not imported from Egypt as a final product; only the raw materials were imported and then melted or manufactured locally.

- The very law amount of Egyptian blue detected in the samples from Jerba is an indicator to the preciosity and rarity of this pigment material, therefore the manufacturer added other compounds as fillers.

- The purity of the comparative sample from Egypt supports that the ideal production process of the Egyptian blue was used in Egypt.

\section{References}

[1] Toulotte, J., (1892). Géographie de l'Afrique chrétienne Proconsulaire, Rennes, Paris.

[2] Regulski, I., (2009). Investigating a new dynasty necropolis at South Saqqara, British Museum Studies in Ancient Egypt and Sudan, Vol. 13, pp: 221-37

[3] Moussa, A., \& Ali, M., (2013). Color alteration of ancient Egyptian blue faience, International Journal of Architectural Heritage, Vol. 7 (3), pp: 261-274.

[4] Fouque, F., (1889). Sur le bleu Égyptien ou Vestorien, Bulletin de la Societe Française de Mineralogie, Vol. 12, pp: 36-38.

[5] Laurie, A., McLintock, W., Miles, F., (1914). Egyptian blue, in: Proceedings of Royal Society, 89, London, pp: 418-429.

[6] Minguzzi, C., (1938). Cuprorivaite, un nuovo Minerale, Periodico di Mineralogia, Vol. 8, pp: 333-345.

[7] Orsega, E., Agnoli, F., \& Mazzocchin, G., (2006). An EPR study on ancient and newly synthesized Egyptian blue, Talanta, Vol. 68, pp: 831-835.

[8] JCPDS, (1967). Jaint committee on powder diffraction standards, Index to the powder diffraction file, American Society for Testing and Materials, Pennsylvania, USA.

[9] Hsu, Sh., (2000). Infrared spectroscopy, in: Settle, f. (ed.) Handbook of instrumental techniques for analytical chemistry, Prentice Hall PTR, New Jersey.

[10] Edreira, M., Feliu, M., FernándezLorenzo, C., \& Martın, J., (2001). Roman wall paintings characterization from cripta del Museo and Alcazaba in Mérida (Spain): Chromatic, Energy dispersive X-Ray fluorescence spectroscopic, X-Ray diffraction and Fourier transform infrared spectroscopic analysis, Analytica Chimica Acta, Vol. 434, pp: 331-345.

[11] Edreira, J., M., Feliu, M., Fernandez-Lorenzo, C., \& Martin, J., (2003). Spectroscopic analysis of roman wall paintings from Casa del Mitreo in Emerita Augusta, Merida, Spain, Talanta, Vol. 59, pp: 11171139.

[12] Mazzocchin, G., Agnoli, F., Mazzocchin, S., \& Colpo, I., (2003). Analysis of pigments from Roman wall paintings found in Vicenza, Talanta, Vol. 61, pp: 565-572.

[13] Mazzocchin, G., Agnoli, F., \& Salvadori, M., (2004). Analysis of Roman age wall paintings found in Pordenone, Trieste and Montegrotto, Talanta, Vol. 64, pp: 732-741.

[14] Coupry, C., \& Lautié, A., (2001). Raman studies on surface of artifacts, Surf Eng, Vol. 17 (3), pp: 246 - 248

[15] Bikiaris, D., Sister D., Sotiropoulou, S., Katsimbiri, O., Pavlidou, E., Moutsatsou, A., \& Chryssoulakis, Y., (1999). Ochre-differentiation through Micro-Raman and Micro-FTIR spectroscopies: Application on wall paintings at Meteora and Mount Athos, Greece, Spectrochimica Acta, Vol. 56 (A), pp: 3-18.

[16] Maravelaki-Kalaitzaki, P., \& Kallithrakas-Kontos, N., (2003). Pigment and terracotta analyses of Hellenistic figurines in Crete, Analytica Chimica Acta, Vol. 497, pp: 209-225.

[17] Lee, L., \& Quirke, S., (2001). Painting materials, , in: Nicholson, T. \& Shaw, I. (eds.), Ancient Egyptian materials and technology, $1^{\text {st }}$ ed., Cambridge University Press, London, pp: 104-120,

[18] Pagès-Camagna, S., \& Colinart, S., (2003). The Egyptian green pigment: It's manufacturing process and links to 
Egyptian blue, Archaeometry, Vol. 45 (4), pp: 637-658.

[19] Mazzocchin, G., Rudello, D., Bragato, C., \& Agnoli, F., (2004). A short note on Egyptian blue, Journal of Cultural Heritage, Vol. 5, pp: 129-133.

[20] Bianchetti, P., Talarico, F., Vigliano, M., \& Ali, M., (2000). Production and characterization of Egyptian blue and Egyptian green frit, Journal of Cultural Heritage, Vol. 1, pp: 179-188.

[21] Kendrick, E., Kirk, C., \& Dann, S., (2005). Structure and color properties in the Egyptian blue family, M1_xM'xCuSi ${ }_{4} \mathrm{O}_{10}$, as a function of $\mathrm{M}$, $\mathrm{M}^{\prime}$ where $\mathrm{M}, \mathrm{M}^{\prime}=\mathrm{Ca}, \mathrm{Sr}$ and $\mathrm{Ba}$, Journal of Dyes and Pigments, Vol. 37 (1), pp: 13-18
[22] Uda, M., Tsunokami, T., Murai, R., Maeda, K., Harigai, I., Nakayama, Y., Yoshimura, S., Kikuchi, T., Sakurai, K., \& Sasa, Y., (1993). Quantitative analysis of ancient Egyptian pigments by external PIXE, Nuclear Instruments and Methods in Physics Research B 75, pp: 476-479.

[23] Bruni, S. Cariati, F., Casadio, F., \& Toniolo, L., (1999). Spectrochemical characterization by Micro-FTIR spectroscopy of blue pigments in different polychrome works of art, Vibrational Spectroscopy, Vol. 20, pp: 15-25. 